EASTERN REVIEW 2018, T. 7

Andrzej Chodubski

\title{
Europejskie wyzwania regionalne a generowanie społeczeństwa obywatelskiego
}

Rozpoznając współczesne zjawiska i procesy przemian europejskich, zauważa się, że dużą uwagę badawczą przykuwają kwestie regionalne ${ }^{1}$ oraz problem budowy tzw. społeczeństwa obywatelskiego ${ }^{2}$. Są one ściśle powiązane ze sobą. Założeniem strategicznym założycieli Unii Europejskiej było kształtowanie wspólnoty obywateli zorientowanych na urzeczywistnianie zasad wolności, demokracji i rządów prawa. Zakładano, że obywatele przestrzeni europejskiej przestrzegać będą praw i obowiązków, wypracowanych przez wszystkich jej członków, wyrażanych w formie prawa. Wskazywano, że obywatelstwo Unii Europejskiej zobowiązuje do umacniania tożsamości europejskiej, aczkolwiek nie powinno zmniejszać tożsamości narodowych społeczeństw zamieszkujących w państwach wchodzących w jej skład. Kształtowanie nowej tożsamości europejskiej wiązano z umacnianiem wartości pokoju, poszanowania praw człowieka i rządów prawa ${ }^{3}$. Podkreślano przy tym, że szczególną wartością powinna być różnorodność kulturowa Europy, że jedność Europy powinna ją generować ${ }^{4}$.

W kształtowaniu się obywatelskiegowymiaru Unii Europejskiej istotną uwagę przywiązuje się do rozwiązań instytucjonalnych ${ }^{5}$. Jednym z nich są regiony, które tworzą: a) określoną wyraźnie rzeczywistość geograficzno-przyrodniczą,

${ }^{1}$ Regiony, red. Z. Brodecki, Warszawa 2005; A. Chodubski, Idea i praktyka nowego regionalizmu a globalizacja cywilizacji, [w:] Regionalizm a globalizacja. Polska - Unia Europejska oraz inne zjawiska i procesy regionalne świata, red. A. Chodubski, H. Dubrzyńska, M. Malinowski, A. Modrzejewski, Gdańsk 2007, s. 9-24.

${ }^{2}$ Unia Europejska a społeczeństwo obywatelskie, red. R. Paradowski, Poznań 2005; K. Trzciński, Obywatelstwo w Europie. Z dziejów idei i instytucji, Warszawa 2006.

${ }^{3}$ K. Łastawski, Od idei do integracji europejskiej, Warszawa 2003; Integracja europejska. Wstęp, red. K.A. Wojtaszczyk, Warszawa 2006.

${ }^{4}$ F. Gołembski, Kulturowe aspekty integracji europejskiej, Warszawa 2008.

5 Społeczeństwo obywatelskie, red. W. Bokajło, K. Dziubka, Wrocław 2001. 
b) stan demograficzny, c) losy historyczne (wspólne dziedzictwo przeszłości),

d) kulturę (wspólne tradycje, zwyczaje, obyczaje), e) specyfikę życia gospodarczego (bogactwa ziemi, rozwój przemysłu, handlu), f) poziom rozwoju cywilizacyjnego (otwartość na nowe zjawiska i procesy życia społeczno-gospodarczego, na postęp naukowo-techniczny, na edukację).

Współczesny świat współtworzą jednocześnie zachodzące procesy unifikacji i dywersyfikacji życia kulturowo-cywilizacyjnego ${ }^{6}$. Rozpoznając procesy unifikacyjne, zwraca się uwagę przede wszystkim na siłę postępu naukowo-technicznego, rozwiązania prawne o zasięgu międzynarodowym czy nowoczesną edukację. W przestrzeni tej ujawnia się narzucanie zewnętrznych wzorów, modeli, paradygmatów zachowań społeczno-politycznych, działań gospodarczych. Dużą siłę w tym względzie zdobywają wzory amerykańskie. Uniwersalizm wiąże się z oswajaniem osiągnięć naukowo-technicznych oraz praktycznym ich stosowaniem w życiu kulturowym. Przemiany dokonujące się współcześnie w tej przestrzeni określa się mianem rewolucyjnych. Zwraca się w tym uwagę na likwidację: a) barier odległości, co wynika z ujawniania się szybkich środków transportu, jak np. samolotu ponaddźwiękowego; b) barier horyzontalnych (przestrzennych), powodowanych rozwojem telekomunikacji - telewizja satelitarna, interaktywna, poczta elektroniczna, zdalny druk, wizjotelefon; c) bariery mnogości powodowanej przez rozwój informatyki i zastosowanie komputerów. A też ciągle doskonalona jest sieć dróg bitych i kolejowych, lotniczych oraz morskich.

Postęp naukowo-techniczny powoduje wprowadzenie do praktyki kulturowo-cywilizacyjnej: a) nowych surowców, materiałów, sposobów uzyskiwania surowców, np. przez zastosowanie ropy naftowej w przemyśle spożywczym; b) nowych źródeł energii - odnawialne źródła, energia słoneczna, geotermiczna, uzyskiwana $z$ oceanów i cieków wodnych, biomasa, energia jądrowa; c) nowych środków pracy - automatyzacja, robotyzacja, komputeryzacja. Rozwój tych przejawów rewolucji naukowo-technicznej jest powiązany takimi technologiami, jak informatyka, telekomunikacja, biotechnologia czy chemia wyspecjalizowana. W życiu kulturowo-cywilizacyjnym szczególne znaczenie ma rosnąca w szybkim tempie informacja, która wymaga właściwego gromadzenia, przetwarzania i przekazywania do właściwych podmiotów życia kulturowego. Powoduje ona zmianę charakteru pracy zawodowej. Ujawnia się coraz większa specjalizacja zawodowa, powstają nowe zawody, a jednocześnie zmniejsza się ich trwałość. Zauważa się, że maszyny przejmują kontrolę nad wykonywaniem zadań polegających na rutynie ${ }^{7}$.

${ }^{6}$ A. Chodubski, Wartości cywilizacji współczesnej a unifikacja i dezintegracja Europy, [w:] Unifikacja i zróżnicowanie się współczesnej Europy, red. B. Fijałkowska, A. Żukowski, Warszawa 2002, s. 16-30.

${ }^{7}$ E. Polak, Przemiany cywilizacji współczesnej w sferze kultury materialnej, Gdańsk 1996, s. 66. 
Procesy te mające charakter globalny są szczególnym wyzwaniem w Europie, w krajach Unii Europejskiej i różnych podmiotach regionalnych. W strategii Unii Europejskiej wiąże się je z wyzwaniem wyrównywania szans w budowie nowej tożsamości europejskiej ${ }^{8}$.

Ważną siłą generującą współczesny obraz życia kulturowo-cywilizacyjnego jest prawo międzynarodowe9. Państwa, podpisując umowy i traktaty międzynarodowe i określając zasady działalności organizacji międzynarodowych, tworzą przepisy prawa międzynarodowego, regulującego stosunki międzynarodowe i stanowiącego podstawy nowego ładu globalnego. Prawo międzynarodowe jest szczególnym rodzajem prawa. Nie jest ono tworzone i narzucane przez władzę nadrzędną, a powstaje na podstawie uzgodnień równorzędnych państw, na zasadzie kompromisów i ustępstw. Nie posługuje się w praktyce kulturowej sankcjami, a w tym instytucjami przymusu. Każde państwo, podpisując odpowiednie dokumenty prawne, zobowiązuje się do ich przestrzegania w rzeczywistości międzynarodowej. Obowiązująca jest zasada dotrzymywania umów. W praktyce kulturowej nie wypracowano efektywnych metod rozstrzygania konfliktów o zasięgu międzynarodowym. Główne sposoby w tym względzie to: a) działania dyplomatyczne (rokowania, mediacje, koncyliacje), b) zachowania bazujące na presji (retorsje, represalia), c) postępowania sądowe, które reprezentuje Międzynarodowy Trybunał Sprawiedliwości (organ ONZ), powołany do rozstrzygania sporów prawnych między państwami.

W przestrzeni międzynarodowych rozwiązań prawnych znajdują się prawa człowieka $^{10}$. Mają one charakter uniwersalny. W Europie urzeczywistniane są przez działania Europejskiej Komisji Praw Człowieka i Europejski Trybunał Praw Człowieka w ramach Rady Europy. Każde z państw ubiegających się o członkostwo w Unii Europejskiej musi dostosować prawodawstwo do norm Europejskiej Konwencji Praw Człowieka.

W kształtowaniu nowej tożsamości europejskiej ważne miejsce wyznacza się edukacji ${ }^{11}$. Przez pojęcie „edukacja europejska” zwykle rozumie się wspólne tradycje i wzory systemów oświatowych ukształtowane w procesie dziejowym. Jest ona rozumiana jako kultywowanie pewnych wartości uniwersalnych, charakterystycznych dla społeczeństw demokratycznych, tj. poszanowania praw człowieka, kształtowania postaw obywatelskich oraz poczucia tożsamości narodowej, określania swojego miejsca w kulturze i hierarchii wartości Europy.

8 Tożsamość regionów w Polsce w przestrzeni europejskiej, red. W. Łukowski, Katowice 2004.

${ }^{9}$ Prawo Unii Europejskiej, t. 1-2, red. J. Barcz, Warszawa 2002.

10 R. Kuźniar, Prawa człowieka. Prawo, instytucje, stosunki międzynarodowe, Warszawa 2000; S. Konopacki, Obywatelstwo europejskie w kontekście członkostwa w Unii Europejskiej, Łódź 2005.

${ }^{11}$ Edukacyjne problemy czasu globalizacji. W dialogu i perspektywie, red. A. Karpińska, Białystok 2003; A. Chodubski, Współczesna edukacja a wektory przemian cywilizacyjnych, „Studia Gdańskie. Wizje i Rzeczywistość" 2012, t. IX, s. 9-21. 
Zgodnie z założeniami Unii Europejskiej ważnym wyzwaniem staje się ujednolicanie rozwiązań instytucjonalnych, takich jak: ustawowy obowiązek szkolny oraz zakres nauczania obowiązkowego, liczba szczebli edukacyjnych w szkolnictwie podstawowym, średnim i wyższym, czas trwania nauki na poszczególnych szczeblach, rodzaje świadectw i dyplomów świadczących o ukończeniu poszczególnych etapów wykształcenia.

Problem edukacji jest w polu uwagi instytucji politycznych, m.in. w związku z urzeczywistnianiem zasady o swobodnym przepływie osób, usług i towarów. Ważnym wyzwaniem staje się w życiu kulturowym zrównanie szans edukacyjnych $w$ ramach europejskiego wymiaru nauczania.

Zauważa się jednak, że nie jest możliwe w pełni urzeczywistnianie ujednoliconego modelu edukacji europejskiej. Wynika to z okoliczności, że Europa jest obszarem historycznie podzielonym pod względem językowym, obyczajowym, religijnym i narodowym. System edukacyjny każdego z krajów ewoluował samodzielnie i w oderwaniu od innych, w warunkach autonomii i niezależności. Wiele jest w nich ogniw dziedzictwa przeszłości będącego dumą poszczególnych narodów, jego różnych wspólnot.

Szczególne zmiany ujawniły się w Unii Europejskiej w dziedzinie szkolnictwa wyższego. W 1992 r. Komisja Europejska opublikowała memorandum, w którym zaproponowała gruntowną reformę przestrzeni akademickiej. W $1999 \mathrm{r}$. została określona w tzw. deklaracji bolońskiej ${ }^{12}$.

Główne tendencje unifikujące i dywersyfikujące współczesne życie kulturowe ujawniają, że rozwiązywanie ich złożonych problemów powoduje umacnianie się ryzyka. Z jednej strony, uprzywilejowaną pozycję zdobywają kreatorzy nowej rzeczywistości cywilizacyjnej oraz z drugiej - pojawiają się coraz szersze kręgi ludzi tzw. wykluczonych, tj. niezdolnych do oswajania znaków postępu naukowo-technicznego, nowych regulacji prawnych.

Za ważną instytucję generowania życia społeczno-politycznego uznaje się demokrację ${ }^{13}$. Podkreśla się, przy tym aktualność twierdzenia Alexisa de Tocqueville'a, że w systemie demokratycznym preferowana jest władza ludzi średnich, co prowadzi do rządów przeciętności. Demokracja według niego nie sprzyja pojawianiu się wielkich przywódców, wybitnych mistrzów duchowego i społecznego życia ${ }^{14}$.

W kształtującej się rzeczywistości informacyjnej ujawnia się globalna społeczność obywatelska. Odchodzi się od wartości tradycyjnego lokalizmu na rzecz wartości uniwersalnych. Ludzie łączą się ponad granicami państw. Ważna jest

12 Integracja europejska. Wstęp..., s. 318-326.

13 A. Chodubski, Granice demokracji: przeszłość i teraźniejszość, [w:] Demokracja bezpośrednia w samorzadzie terytorialnym, red. M. Marczewska-Rytko, S. Michałowski, Lublin 2012, s. $17-28$.

${ }^{14}$ M. Król, Słownik demokracji, Kraków 1989, s. 93. 
w tym względzie komunikacja językowa oraz posługiwanie się urządzeniami informatycznymi. W przestrzeni tej następuje odchodzenie od dziedzictwa przeszłości (nierzadko świadomego zapominania o nim) na rzecz doraźnej teraźniejszości, naśladowania obcych (często anglosaskich) wzorów postaw, zachowań, wartości. W ślad za tym ugruntowuje się skrajny indywidualizm ludzi, a przy tym następuje dehumanizacja wszelkich więzi społecznych.

Stratedzy budownictwa naszej rzeczywistości kulturowo-cywilizacyjnej wskazują jednak, że kulturowa różnorodność jest niezbędna dla ludzkości. Podkreślają, że jest ona elementem składowym w procesach unifikacji. Ludzkość powinna uczestniczyć w obu procesach, jako że dla społeczności lokalnych homogenizacja kulturowa, standaryzacja nie jest często akceptowana, a też szerokie kręgi społeczeństwa nie są w stanie oswajać znaków nowoczesności, które ulegają szybkim zmianom w czasie. W tej sytuacji narastają bunty, protesty, dochodzi do konfliktów na tle cywilizacyjnym.

Zakłada się, że instytucją przeciwdziałającą narastaniu konfliktów jest regionalizacja $^{15}$. Regiony są obecnie różnie definiowane. W procesie dziejowym odnoszono je do zjawisk geograficznych, przestrzennych. Różnie je pojmowano w poszczególnych krajach Europy. Ogólnie jednak w ich pojmowaniu przeplatają się elementy rzeczywistości geograficzno-historyczno-demograficzno-kulturowo-gospodarczo-administracyjnej.

Pierwszeństwo zdobywa jej przestrzeń, którą wyznaczają zwykle naturalne granice. W danej przestrzeni osiedlająca się ludność wypracowuje dominującą wspólną kulturę gospodarczą oraz zwyczaje i obyczaje, które współcześnie nierzadko postrzega się jako folklor. Ludność danych regionów zespalają losy polityczne, a w tym zagrożenia zewnętrzne. Regiony są różnie określane w krajach europejskich ${ }^{16}$. Pod nazwą „regiony” istnieją we Francji i Hiszpanii, we Włoszech, Grecji jednostki określane wspólnotami autonomicznymi, w Austrii i Niemczech - landami, w Finlandii, Szwecji, Holandii - prowincjami, w Danii - gminami-okręgami, w Wielkiej Brytanii - terytoriami, w Irlandii - hrabstwami.

W Polsce pojęcie to ma przede wszystkim rodowód geograficzno-przyrodniczy. W podziale administracyjnym zwykle wymienia się 12 regionów, tj. 1) Pomorze Zachodnie (Szczecin), 2) Pomorze Nadwiślańskie (Gdańskie; Gdańsk), 3) Warmińsko-Mazurski (Olsztyn), 4) Podlasie (Białystok), 5) Mazowsze (Warszawa), 6) Ziemię Łęczycko-Sieradzką (Łódź), 7) Wielkopolskę (Poznań), 8) Dolny Śląsk (Wrocław), 9) Górny Śląsk (Katowice), 10) Ziemię Krakowską (Kraków), 11) Małopolskę Wschodnią (Rzeszów), 12) Ziemię Lubelską (Lublin). Odwołując się do dziedzictwa przeszłości, wymienia się najczęściej sześć jednostek regionalnych, tj. 1) Wielkopolskę, 2) Pomorze, 3) Kujawy, 4) Mazowsze, 5) Śląsk, 6) Małopolskę.

15 A. Chodubski, O renesansie lokalizmu, „Zeszyty Chojnickie” 1997, nr 1, s. 9-18.

${ }^{16}$ I. Pietrzyk, Polityka regionalna Unii Europejskiej i regiony w państwach członkowskich, Warszawa 2000; W stronę wspólnoty regionalnej, red. J. Szomburg, Gdańsk 2006. 
Zainteresowanie rzeczywistością regionalną w Polsce postrzegane jest dychotomicznie $^{17}$. Z jednej strony obserwuje się dla niej akceptację jako umacnianie lokalizmu, ujawnianie się możliwości decydowania o kierunkach rozwoju społeczno-gospodarczego przez społeczności lokalne, jako możliwość rozwiązywania problemów z punktu widzenia interesów lokalnych, z drugiej zaś - postrzega się, że obecnie jest to proces odgórny, wynikający ze strategii przemian europejskich oraz wyzwań dywersyfikacji życia kulturowego. Nierzadko regiony traktuje się jako czarodziejski środek na rozwiązywanie dolegliwości, jakich doznaje obywatel ze strony władzy.

We współczesnych przemianach europejskich ważnym dokumentem określającym wagę regionów jest uchwalona w 1988 r. przez Parlament Europejski Wspólnotowa Karta Regionalizacji. Jest ona aneksem do Rezolucji o polityce regionalnej. Dokument jest apelem parlamentarzystów zwracających się do rządów i parlamentów państw członkowskich o uregulowanie prawne na szczeblach krajowych zagadnień regionalnych. W Karcie (art. 1) zamieszczono definicję regionu, wskazując, że rozumie się go jako terytorium, które z geograficznego punktu widzenia stanowi wyraźną całość bądź też stanowi jednolity kompleks terenów, które tworzą zamkniętą całość, a których ludność charakteryzują określone wspólne elementy, przy czym chciałaby ona utrwalić i rozwiązać prawnie wynikające z nich właściwości, aby pobudzić postęp kulturalny, społeczny i gospodarczy ${ }^{18}$.

W praktyce europejskiej, a w tym w Polsce, w latach 90. XX w. podział na regiony postrzegano jako proces modernizacji władzy publicznej, a w mniejszym stopniu ujawniło się nimi zainteresowanie oddolne społeczności lokalnych. Odgórnie wyznaczano regionom rolę narzędzia i środka w decentralizacji politycznej państwa. Nośne stały się kwestie etniczne i wyznaniowe, co wiązano z rozwojem ruchu społecznego, mającego promować odrębność poszczególnych regionów, zwłaszcza w przestrzeni społeczno-kulturalnej. $\mathrm{W}$ tej sferze ujawniał się swoisty renesans odrębności etnicznej i językowej. Wyznaczano regionom ważne zadanie w uwolnieniu społeczeństwa od ładu scentralizowanego. W ślad za tym państwo podjęło działania na rzecz rozwoju polityki regionalnej ${ }^{19}$. Jej celem stało się wprowadzenie zmian w organizacji zarządzania administracyjnego.

W praktyce kulturowej regiony zostały ukierunkowane na dokonanie przewartościowań cywilizacyjnych, wyrażające się m.in. w takich relacjach, jak: a) „swoi” - „obcy”, b) „,entrum” - „peryferia”, c) „uniwersalizm” - „lokalizm”, d) „dziedzictwo przeszłości, tradycja” - „nowoczesność”, e) „ogół społeczeństwa, masy" - ,jednostka”. W ślad za tym zaczęto definiować region jako twór, który obejmuje wytworzony (lub konstruowany) w dłuższym czasie i ulokowany w określonej przestrzeni, wyodrębniony układ społeczno-kulturowy bazujący na

${ }^{17}$ Regionalizm Polski u progu XXI wieku, red. S. Bednarek i in., Wrocław 1994.

${ }_{18}$ B. Zawadzka, Województwo i region. Wnioski z doświadczeń francuskich, Warszawa 1993, s. 36.

${ }_{19}$ Polska regionalna i lokalna w świetle badań, red. G. Grzelak, Warszawa 2007. 
trwałych podstawach najczęściej tradycji o kulturowej, ale także administracyjno-politycznych, ekonomicznych, obejmujący w różnym stopniu powiązania wzajemne jednostki i zbiorowości lokalnej, ich kulturę oraz różne formy wspólnych działań społecznych odniesionych do poszczególnych zbiorowości, jak i do ogółu mieszkańców wydzielonego układu, które pozwalają traktować go jako wyodrębnioną całość. Wyodrębniony lub najczęściej kształtujący się układ społeczno-kulturowy jest zróżnicowany społecznie i kulturowo, cechuje się współdziałaniem i rywalizacją, jednocześnie jest $\mathrm{w}$ różnym stopniu połączony ${ }^{20}$.

Europejskie wyzwania regionalne są wiązane przede wszystkim z decentralizacją życia kulturowego, a w tym społeczno-politycznego, jak i gospodarczego. $\mathrm{W}$ tej sytuacji zacierają się granice między centralną decyzyjnością a peryferyjnością, której nierzadko wyznacza się miejsce zaplecza dla ładu centralnego. Zacierając podziały te, dokonuje się przewartościowań kulturowych, m.in. zwracając uwagę na pogranicza (kresy) ${ }^{21}$. Odchodzi się od identyfikacji pogranicza z zacofaniem kulturowym, zapóźnieniem cywilizacyjnym, zauważając, że jest to wyjątkowa przestrzeń w przemianach kulturowo-cywilizacyjnych. W niej ukształtowane są bowiem najbardziej pożądane cechy obywatelskości, takie jak: a) odwaga w działaniach kulturowych, b) przedsiębiorczość, c) decyzyjność jednostek, jak i wspólnot, d) krytycyzm wobec otaczającej rzeczywistości, a w tym wobec ujawniających się nowinek ideologicznych, e) przystosowawczość do zmieniających się do nowych warunków, sytuacji, okoliczności. Zauważa się, że z przestrzeni kresowych wywodzą się najczęściej luminarze nauki, kultury i sztuki, co wynika z wyrastania ich w rzeczywistości wielokulturowej, ścierania się w przestrzeniach tych różnych wpływów, oddziaływań, jak też otwartości na nowe zjawiska kulturowe.

Uniwersalizm wobec peryferii wiąże się zwykle z narzucaniem wzorów, modeli, paradygmatów zachowań społeczno-politycznych oraz wartości gospodarczych. Powoduje on oswajanie w nich osiągnięć naukowo-technicznych oraz wprowadzanie ich do praktyki kulturowej. Ujawnia się przy tym wypieranie wartości moralnych na rzecz regulacji prawnych. Ważną rolę w tym względzie pełni przestrzeń edukacyjna, w której kształtowanie wartości uniwersalnych zdobywa pierwszeństwo przed kształceniem lokalizmu, które staje się rzeczywistością fakultatywną. Edukacja w przestrzeni lokalnej wiąże się zwykle z przypominaniem zasług jednostek zasłużonych dla danych społeczności. Istotne jest też odwoływanie się do symboli, mitów regionalnych, przypominanie nierzadko niechlubnych kart z dziejów. Pozytywne wzory postaw, zachowań obywatelskich stają się społecznym zobowiązaniem do ich naśladowania i kontynuacji. Obecnie przestrzeń ta budzi kontrowersyjność oraz nierzadko emocjonalność. Powodowane

${ }^{20}$ A. Sadowski, Wielokulturowe społeczeństwo regionalne, [w:] Społeczności lokalne. Teraźniejszość i przyszłość, red. B. Jałowiecki, W. Łukowski, Warszawa 2005, s. 131.

${ }^{21}$ A. Chodubski, Kresy jako specyficzna wartość cywilizacyjna, [w:] Kultura pogranicza. Pogranicze kultur, red. A. Bobryk, Siedlce-Pułtusk 2005, s. 51-67. 
jest to zwłaszcza urzeczywistnianiem odgórnej polityki historycznej. Wielu zasłużonych ludzi przestrzeni lokalnych ze względów ideowo-politycznych ,skazuje się na niepamięć", a ich miejsce wyznacza się nowym bohaterom; przy czym nierzadko budzącym sprzeciw społeczności lokalnych. Kontrowersje budzi przestrzeń wznoszenia pomników, fundowania tablic pamiątkowych, nadawania nazw ulicom, osiedlom, instytucjom życia publicznego. Rzeczywistość ta powoduje osłabienie identyfikacji z regionalizmem, lokalnością, dziedzictwem przeszłości. Ważną rolę w tym względzie pełnią media, które stają się podmiotem generującym nowe, pożądanie wartości ideowo-polityczne.

W kształtującej się rzeczywistości regionalnej w krajach Unii Europejskiej nośne wyzwania wyznaczono instytucji „euroregionu” ${ }^{\text {"22 }}$. Przyjęto rozumieć przez nią porozumienia przygranicznych regonów dotyczących współpracy transgranicznej. W rzeczywistości tej nie przewidywano tworzenia wspólnych organów administracji publicznej, które mogłyby w jakiejś mierze uszczuplać suwerenność państwa wobec danego obszaru. Zakładano, że powstające podmioty (euroregiony) nie będą wyłączane z podległości prawnej państw, na pograniczu których są tworzone. Zgodnie z konwencją europejską o współpracy transgranicznej ich celem powinno być umacnianie i rozwój stosunków sąsiedztwa między samorządami lub władzami terytorialnymi dwu lub więcej układających się stron oraz zawieranie umów i porozumień służących temu celowi ${ }^{23}$. W praktyce kulturowej działalność euroregionów ukierunkowana została na wymianę kulturową, turystykę, ułatwienia wzajemnych kontaktów (przejścia graniczne, transport), ochronę środowiska naturalnego, a także przygraniczną współpracę społeczno-gospodarczą.

Ideę tworzenia euroregionów postrzegano jako istotne wyzwanie sprzyjające rozwojowi cywilizacyjnemu przestrzeni kresowych, ale też zwracano uwagę na zjawiska mogące mieć negatywne konsekwencje dla poszczególnych państw oraz dla rzeczywistości międzynarodowej. Orientując się jednak na korzyści funkcjonowania euroregionów, podkreślano wagę: a) współpracy transgranicznej w ożywianiu i wzbogacaniu materialnym i niematerialnym życia lokalnego oraz regionalnego (korzyści komparatywne, ekonomika skali, efekty synergiczne); b) współpracy transgranicznej w uspołecznieniu stosunków zewnętrznych państwa (włączenie społeczeństwa w stosunki międzynarodowe); c) współpracy transgranicznej we współtworzeniu powiązań subregionalnych w Europie (zwłaszcza w Europie Środkowej i Wschodniej), a w tym w odchodzeniu od koncepcji „granicy - muru” na rzecz idei „granicy - miejsca spotkań”; d) współpracy transgranicznej umacniającej bezpieczeństwo sąsiedztwa, jak też władz lokalnych. Główne argumenty formułowane przeciw tworzeniu euroregionów dotyczyły: a) zagrożenia integralności i suwerenności państw, w przestrzeni których były

22 W. Malendowski, M. Ratajczak, Euroregiony. Pierwszy krok do integracji europejskiej, Wrocław 1998, s. 41.

${ }^{23}$ B. Zawadzka, Województwo..., s. 50. 
sytuowane; b) wywierania dużego wpływu mniejszości narodowych na sprawy państwa; c) niekontrolowanego napływu imigrantów wobec osłabienia granic państw w przestrzeniach transgranicznych; d) możliwości mieszania się organizacji międzynarodowych ${ }^{24}$.

Współdziałanie transgraniczne stało nowym wyzwaniem i obowiązkiem w środowisku międzynarodowym, ujawniającym możliwości, m.in. wynikające z upodmiotowienia społeczności lokalnych, jak i bariery - konieczność dokonania przewartościowań świadomościowych, zwykle osadzonych w sferze mitów i stereotypów, uprzedzeń ${ }^{25}$. Postrzeganie wzajemne narodów i grup etnicznych w przestrzeni stereotypów ma bogate korzenie kulturowe. W najstarszych opisach Europejczyków pojawiały się charakterystyki typu:

Kłócili się z powodu pochodzenia różnych krajów i wzajemnie ubliżali, wadząc się, znieważając i liczne przeciwko sobie rzucali bezwstydne szyderstwa i zniewagi. Anglików ogłaszając za pijaków i ognistych; tych z Francji za pysznych, lubieżnych i mających budowę kobiecą; Niemców za szalonych i że na ucztach swoich bezwstydnie się wyrażali; Normanów za zarozumiałych i pysznych [...]. Tych zaś, którzy z Burgundii pochodzili, uważali za głupich i nikczemnych. Brytów osądzając jako lekkomyślnych i włóczęgów, zarzucali im śmierć Artura. Lombardczyków uważali za chciwych, gwałtownych, Sycylijczyków za tyranów i okrutnych, Rzymian za buntowniczych i gwałtownych ${ }^{26}$.

W kształtowaniu się nowego ładu cywilizacyjnego ważne wyzwania wiążą się z budową społeczeństwa obywatelskiego. Ważną przestrzeń jego urzeczywistnienia wyznacza się regionom. Założeniem w funkcjonowaniu społeczeństwa obywatelskiego jest uznawanie pluralizmu ideowo-politycznego, uczestnictwo w organizacji pokojowych zgromadzeń, bezpośrednie uczestnictwo w życiu społecznym i politycznym. W kulturze politycznej - dążenie do pełnego urzeczywistnienia idei wolności, w tym sumienia i religii, wyrażania swoich poglądów; do pielęgnowania wartości: solidarności, lojalności, więzi kulturowych.

Za niezbędne warunki do funkcjonowania współcześnie społeczeństwa obywatelskiego uznaje się m.in.: a) funkcjonowanie władzy w określonych granicach i na podstawie prawa, b) w systemie źródeł prawa uwzględnianie interesów obywateli, c) istnienie prawnego systemu ochrony praw i wolności obywateli, a w tym istnienie instytucji gwarantujących przestrzeganie praw, d) gwarantowanie obywatelom możliwości uczestnictwa w życiu społecznym, jak też gwarantowanie prawne tworzenia organizacji wyrażających interesy obywateli ${ }^{27}$.

${ }^{24}$ M. Kulesza, Europa regionów, [w:] Europa na co dzień, red. M. Taraszkiewicz, Warszawa 1997, s. A-X/18.

${ }^{25}$ Z. Radłowski, J. Wojtczak, Jak narody widza siebie nawzajem. O Polakach w Europie, Warszawa 1994, s. 60.

${ }^{26}$ P. Broda-Wysocki, Rozwój społeczeństwa obywatelskiego w Polsce, Warszawa 2003; Społeczeństwo obywatelskie, red. M. Witkowska, H. Wierzbicki, Warszawa 2005, s. 12.

${ }^{27}$ A. Chodubski, Tradycyjne wartości polskiej kultury politycznej a znaki cywilizacyjne wspótczesnych wyzwań globalnych, [w:] Poziomy aktywności Polski w środowisku międzynarodowym, red. T. Łoś-Nowak, A. Dudek, Legnica 2002, s. 132-146. 
W myśli społeczno-politycznej, zwłaszcza liberalnej, społeczeństwo obywatelskie powołane jest do promowania indywidualizmu, aktywności ekonomicznej jednostki. Obywatelskość postrzega się jako nieposłuszeństwo wobec decyzji odgórnych państwa, a zwłaszcza ograniczających indywidualizm działania. W myśli konserwatywnej „społeczeństwo obywatelskie” jest przywiązaniem do tradycji, co umacnia wartości lokalnej odpowiedzialności.

Zgodnie z założeniami Unii Europejskiej społeczeństwo obywatelskie występuje w państwie prawa - prawa konstytucyjnego, praworządnego, w którym stosunki między organami państwowymi a obywatelami i ich organizacjami określone są przez właściwe normy prawne. W regulacjach prawnych szczególne znaczenie przywiązuje się do obywatelstwa.

Kształtowanie społeczeństwa obywatelskiego jest znakiem dywersyfikacji życia kulturowo-cywilizacyjnego. Ujawniają się w nim takie znaki, jak: a) odchodzenie od modelu państwa represyjnego na rzecz idei urzeczywistniania demokracji, b) umacnianie idei autonomii społeczeństwa wobec państwa, c) umacnianie roli i znaczenia organizacji samorządowych oraz instytucji pozarządowych, d) umacnianie pozycji kulturowej jednostki (i jej partycypatywności), f) zastępowanie filozofii panowania ideą współistnienia, partnerstwa, g) tolerancja wobec różnych systemów wartości, różnorodność kultur i subkultur. Obywatelskość jest postrzegana jako aktywne uczestnictwo jednostki w życiu publicznym, zwłaszcza w podejmowaniu decyzji.

Społeczeństwo obywatelskie jest rzeczywistością generowaną przez określone wzory, modele, paradygmaty ujmowane w ład normatywny. Na gruncie europejskim powszechnie uznaje się poszanowanie dla ładu ustrojowego, współtworzonego przez struktury ustawodawcze, wykonawcze i sądownicze. Obok nich uznaje się funkcjonowanie organów służących publicznemu wyrażaniu opinii (środków masowego przekazu), instytucji wyznaniowych (kościołów oraz innych podmiotów życia wyznaniowego i religijnego), sił zbrojnych, placówek kształcenia i wychowania (od przedszkoli do uniwersytetów), organizacji życia społeczno-kulturalnego.

W polskiej przestrzeni kulturowej obywatelskość kształtowana jest w długim procesie dziejowym. Wyraża się ona w: a) dążeniu do funkcjonowania $\mathrm{w}$ sferze wolności politycznej, b) samorządności społeczno-gospodarczej, c) unijności w sferze relacji zewnętrznych. Aczkolwiek hamowały je takie okoliczności, jak: a) narzucane systemy polityczne państw zaborczych, b) biurokracja, c) nadmiar kontroli i represje (co powodowało, że instytucje publiczne utożsamiano $\mathrm{z}$ aparatem ucisku, przemocy).

Kształtowanie obywatelskości w polskim życiu kulturowo-cywilizacyjnym wiąże się z budową nowej samoświadomości. Ujawnia się w tym względzie potrzeba nowego definiowania instytucji lokalnych, m.in. władz samorządowych, organizacji życia społecznego, tworzenia struktur integracji lokalnej, jako że obserwuje się obecnie pierwszeństwo podmiotów unifikujących życie regionalne i lokalne; następuje przy tym obumieranie wartości autochtonicznych, co powodują przede 
wszystkim ruchy migracyjne ludności, zmiany form pracy zawodowej (zmieniających tradycyjne profesje branżowe), a następuje zatrudnienie w sferze szeroko rozumianych usług, często w znacznej odległości od miejsca zamieszkania. W ślad za tym następuje nieidentyfikowanie się z lokalnymi instytucjami życia publicznego (edukacyjnymi, kulturalnymi, rozrywkowymi, ochrony zdrowia). Często miejscowość zamieszkiwana staje się tzw. sypialnią. I dalej, obserwuje się atomizację życia sąsiedzkiego, wyobcowanie w lokalnej rzeczywistości kulturowej.

Kształtowanie społeczności obywatelskiej wpisuje się w strategię budowy cywilizacji informacyjnej. Zauważa się, że mimo ujawniającego się indywidualizmu, partycypatywności jednostek i grup społecznych, w wymiarze życia kulturowego ważną rolę wyznacza się etosowi obywatelskiemu. Jego syntezą jest aktywność i odpowiedzialność obywateli, łączenie indywidualnej zaradności z myśleniem kategoriami dobra wspólnego.

Społeczeństwu obywatelskiemu przypisuje się różne funkcje. Ma ono chronić sferę społeczną i prywatną przed ingerencją państwa. Wskazuje się też, że powinno w swej przestrzeni kształtować ludzi do partycypacji w rządzeniu państwem, uczyć poszanowania dla demokracji. Nierzadko pojęcie „społeczeństwo obywatelskie" zastępowane jest mianem demokracji.

W refleksji uogólniającej należy stwierdzić, że: 1) procesy regionalizacji, jak i budowy społeczeństwa obywatelskiego są ważnym wyzwaniem ujawniającym się we współczesnej unifikacji i dywersyfikacji świata; 2) istotną rolę wyznaczono im w strategii politycznej Unii Europejskiej; 3) w ich rzeczywistości zderzają się wartości dziedzictwa przeszłości, nierzadko sytuujące się w przestrzeni zmityzowanej z wyzwaniami ideowo-politycznymi procesów globalizacyjnych; 4) w urzeczywistnianiu obu wyzwań ważną rolę pełni świadomość społeczno-polityczna i cywilizacyjna; 5) oba procesy, sytuujące się w przestrzeni dywersyfikacji politycznej - upodmiotawiające ludzi i przestrzeń, ulegają obecnie silnemu wpływowi megatrendów przemian cywilizacyjnych.

\section{Bibliografia}

Broda-Wysocki P., Rozwój spoleczeństwa obywatelskiego w Polsce, Warszawa 2003.

Chodubski A., Granice demokracji: przeszłość i teraźniejszość, [w:] Demokracja bezpośrednia w samorzadzie terytorialnym, red. M. Marczewska-Rytko, S. Michałowski, Lublin 2012.

Chodubski A., Idea i praktyka nowego regionalizmu a globalizacja cywilizacji, [w:] Regionalizm a globalizacja. Polska - Unia Europejska oraz inne zjawiska i procesy regionalne świata, red. A. Chodubski, H. Dubrzyńska, M. Malinowski, A. Modrzejewski, Gdańsk 2007.

ChodubskiA., Kresy jako specyficzna wartość cywilizacyjna, [w:] Kultura pogranicza. Pogranicze kultur, red. A. Bobryk, Siedlce-Pułtusk 2005. 
Chodubski A., O renesansie lokalizmu, „Zeszyty Chojnickie” 1997, nr 1.

Chodubski A., Tradycyjne wartości polskiej kultury politycznej a znaki cywilizacyjne wspótczesnych wyzwań globalnych, [w:] Poziomy aktywności Polski w środowisku międzynarodowym, red. T. Łoś-Nowak, A. Dudek, Legnica 2002.

Chodubski A., Wartości cywilizacji współczesnej a unifikacja $i$ dezintegracja Europy, [w:] Unifikacja i zróżnicowanie się współczesnej Europy, red. B. Fijałkowska, A. Żukowski, Warszawa 2002.

Chodubski A., Współczesna edukacja a wektory przemian cywilizacyjnych, „Studia Gdańskie. Wizje i Rzeczywistość" 2012, t. IX.

Edukacyjne problemy czasu globalizacji. W dialogu i perspektywie, red. A. Karpińska, Białystok 2003.

Gołembski F., Kulturowe aspekty integracji europejskiej, Warszawa 2008.

Integracja europejska. Wstęp, red. K.A. Wojtaszczyk, Warszawa 2006.

Konopacki S., Obywatelstwo europejskie w kontekście członkostwa w Unii Europejskiej, Łódź 2005.

Król M., Słownik demokracji, Kraków 1989.

Kulesza M., Europa regionów, [w:] Europa na co dzień, red. M. Taraszkiewicz, Warszawa 1997.

Kuźniar R., Prawa człowieka. Prawo, instytucje, stosunki międzynarodowe, Warszawa 2000.

Łastawski K., Od idei do integracji europejskiej, Warszawa 2003.

Malendowski W., Ratajczak M., Euroregiony. Pierwszy krok do integracji europejskiej, Wrocław 1998.

Pietrzyk I., Polityka regionalna Unii Europejskiej i regiony w państwach członkowskich, Warszawa 2000.

Polak E., Przemiany cywilizacji współczesnej w sferze kultury materialnej, Gdańsk 1996.

Polska regionalna i lokalna w świetle badań, red. G. Grzelak, Warszawa 2007.

Prawo Unii Europejskiej, t. 1-2, red. J. Barcz, Warszawa 2002.

Radłowski Z., Wojtczak J., Jak narody widza siebie nawzajem. O Polakach w Europie, Warszawa 1994.

Regionalizm Polski u progu XXI wieku, red. S. Bednarek i in., Wrocław 1994.

Regiony, red. Z. Brodecki, Warszawa 2005.

Sadowski A., Wielokulturowe społeczeństwo regionalne, [w:] Społeczności lokalne. Teraźniejszość i przyszłość, red. B. Jałowiecki, W. Łukowski, Warszawa 2005.

Społeczeństwo obywatelskie, red. W. Bokajło, K. Dziubka, Wrocław 2001.

Społeczeństwo obywatelskie, red. M. Witkowska, H. Wierzbicki, Warszawa 2005.

Tożsamość regionów w Polsce w przestrzeni europejskiej, red. W. Łukowski, Katowice 2004. Trzciński K., Obywatelstwo w Europie. Z dziejów idei i instytucji, Warszawa 2006.

Unia Europejska a społeczeństwo obywatelskie, red. R. Paradowski, Poznań 2005.

$W$ stronę wspólnoty regionalnej, red. J. Szomburg, Gdańsk 2006.

Zawadzka B., Województwo i region. Wnioski z doświadczeń francuskich, Warszawa 1993. 
Andrzej Chodubski

\section{Европейские региональные вызовы и генерирование гражданского общества}

Автор замечает, что в настоящее время ученые начинают верить, что феномен перемен в Европе сильно связан с построением и развитием гражданского общества. Гражданское общество было одной из основных целей основателей Европейского союза. Сегодня это все еще одно из самых важных заданий для адептов союза, которое тесно связанно с соблюдением гражданских прав во всех странах ЕC, а также с вопросами разделения схожих ценностей всеми участниками союза. По мнению автора это влияет на создание еврорегионов, которые в свою очередь означают правовое и институциональное сотрудничество между трансграничными регионами каждой страны-участницы ЕС. Этот род сотрудничества является также частью явления гражданского общества. В последующей части статьи автор называет также необходимые для создания гражданского общества факторы.

Ключевые слова: гражданское общество, еврорегионы, ценности Европейского Союза.

\section{Andrzej Chodubski}

\section{European challenges of regionalism and making civil society}

The author notes that nowadays the researchers start to believe that the phenomenon of change in Europe is strongly connected with the construction and development of civil society. Achieving a civil society was one of the fundamental goals of the European Union's founders. Today, it is still one of the most important tasks for EU supporters. It is closely related to the observance of civil rights in individual countries of the European Union, and sharing similar values by all the Union's assets.

Universal values are becoming increasingly important for EU citizens. According to the author, this has an impact on the formation of Euroregions. Euroregions mean legal and institutional cooperation between cross-border regions of individual countries. This type of cooperation is also part of the phenomenon of civil society. In the further part of the article, the author mentions factors that are indispensable for the creation of a civil society.

Keywords: civil society, euroregions, values of the European Union. 